\title{
Psychological Analysis of the Main Character in Stephenie Mayer's Twilight
}

\author{
Made Subur ${ }^{1}$, I Komang Jopi Indrawan ${ }^{2}$ \\ \{made.subur@gmail.com ${ }^{1}$,jopi.indrawan@gmail.com² ${ }^{2}$ \} \\ ${ }^{1,2}$ Faculty of Letters, Universitas Warmadewa Denpasar-Bali, Indonesia
}

\begin{abstract}
This study was motivated by psychological aspects of the main character and aspects that affect the psychology of the main character. The method used in this research was library research. The data are taken from a novel entitled Twilight (2005) by Stephenie Meyer. The data about the psychology of the main character after are collected by reading the novel and by finding out the data that belong to the main characters is psychology. Then they are classified in accordance with the problem discussed. The data collected are analyzed qualitatively based on the theoretical basis and presented in descriptive method. In analyzing the psychological of the main character, the theory used is the character and the psychological theories, as the main theory applied the theory from William Kenny (1996). The results of the research are analyzed descriptively, and it was supported by explanation and examples. The concepts about the main character are also taken from the supporting theories. Based on analysis of the main character's psychology of Twilight, it focus on the five aspects of psychological elements, namely the main character's motivation, wants, emotions, appetites, and feelings.
\end{abstract}

Keywords- Psychological, main character, novel

\section{Introduction}

Literature can help us to develop mature sensibility for all things, especially human being, because it exercises our emotions through arousing our interest, concern, tension, excitement, laughter, and sympathy. It offers pleasure for everyone who reads it. It has also an element of entertaining or entertainment that gives pleasure. There are three major types of literary work that can be observed, love of them prose. Prose is a literary work that is very interesting to be read. A novel is a form of imaginative literature that has been favorite for both the writers and readers. [1] A novel is a picture of real life and manner and of the time in which it was written. The lengths of the novels permit expensiveness in space as well as in time. So, it is not surprising that most society have been a favorite subject of novelist.

In novel, there are two elements that can be found to build up its structure such us intrinsic and extrinsic ones. The intrinsic aspects are the inner elements which builds up the structure of a literary work. All of the elements have functionally a relation to one another. The extrinsic aspects may merely attempt to interpret literature in the light of its social context and its 
antecedents, I most cases, it becomes causal explanation, profession to account for literature, to explain it. Character becomes one of the most important aspects of novel, a character is obviously relevant to as and to our experience if he is like ourselves or like others whom we know [2], that is interesting to be analyzed because the character twilight (2005) will reveal an idea of the story itself and understand the contents of the story.

Twilight (2005) by Stephenie Meyer is chosen to be searched because the aspects psycho of the main character are described plentifully in the novel, Psychology is scientific study of the activities of individual [3], and researcher very interested in this story and want to learn psychology in this novel. Some previous related research has been carried out. One of them was about psychological analysis of Santiago's motivation to struggle far out into the sea as reflected in Hemingway's the old man and the sea [4]. The entire of the analysis in the research was describing the Santiago based on the psychological aspect. Another previous research was about psychological approach on emotion analysis of the main character Evan Taylor in August Rust Movie by using James-Lange Theory. The main emotions are visible in Evan Taylor experiences. They are happiness, satisfaction as positive emotions and fear, anger, sadness as negative ones. All the emotions are motivated by the music [5]. Based on the previous studies, therefore this present study is conducted which has aims to find out the psychological aspects of the main character and aspects that affect the psychology of the main character.

\section{Method}

The data are taken from a novel entitled Twilight [6]. The novel is chosen because in this novel researcher could find the data about the psychology of its main character. The twilight (2005) by Stepenie Meyer is very successful novel in the world and has become the big movie. The method used in this research was library research. The data about the psychology of the main character after are collected by reading the novel and by finding out the data that belong to the main characters is psychology. Then they are classified in accordance with the problem discussed. The data collected are analyzed qualitatively based on the theoretical basis and presented in descriptive method. The results of the research are analyzed descriptively, and it was supported by explanation and examples.

\section{Result And Discussion}

The physiological aspect of the main character conveyed in a fictional story is related to the way the character thinks of feelings and actions in the story. It can be said that this aspect of the main character involves human motivation, wants, emotions, appetites, feelings. All these aspects discussed in detail following based on data collection from the novel titled "Twilight" by Stephanie Meyer's.

\section{A. Human Motivation}

The first motivation of the main character is the motivation to go narrated in this fiction as seen in the following quote.

"I couldn't pause and admire my truck again as I wanted; I was in a hurry to get out of the misty wet that swirled around my head and clung to my hair under my hood." (Page 12)

Here the main character wants to see the pickup he likes but because of the reason he is in a hurry he didn't have time to do that. In a hurry to go do activities like being late. 
The second motivation illustrated by the narrator on the main character is his attention focused on Edward. Can be seen from this quote.

As I walked down the aisle to introduce myself to the teacher and get my slip signed, I was watching him surreptitiously. (page 23)

The main character's attention is to pay attention to Edward even though he still has activities such as introducing himself to the teacher.

The third motivation of the main character is the curiosity narrated in this fiction as seen in the following quote.

I couldn't stop myself from peeking occasionally through the screen of my hair at the strange boy next to me. (Page 24)

Based on the above quote the main character about his curiosity. she could not help watching the man sitting next to him.

The fourth motivation of the main character told in this story is to make a shopping list. Her want to make a shopping list can be seen in the following quote:

"I also found out that he had no food in the house. So I had my shopping list and the cash from the jar in the FOOD MONEY labelled cupboard, and I was on my way to the Thriftway". (page 32)

Based on the above quote the activity that the main character does is make a grocery list. Here the main character wants to eat but there's nothing in his house, because her father doesn't store food. So he finally began to change his home activities by making a grocery list for food at her home.

The five motivation of the main character told in this story is she wants to invite Edward to go on a picnic. Her want to take a picnic can be seen in the following quote:

"So are you going? this Saturday, I mean? "I was hoping he would, even though it seemed impossible. I couldn't picture him loading up to the carpool whit the rest of the kids from school; he didn't belong in de same world. But just hoping that he might give me the first twinge of enthusiasm I felt feel the out thing. "Where are you all going, exactly?" He was still looking ahead, expressionless "" Down to La Push, to first Beach. "I studied his face, trying to read it. His eyes seemed to narrow infinitesimally, He glanced down at me from the corner of his eye, smiling wryly. "I really don't think I was visited." (Page 110) "

With regard to the above quote, it can be said that the narrator of the story illustrates the activities of the main character to take a picnic, seen from here Bella's very hope great to invite Edward and want him to be there with him because he can talk to him.

B. Wants the main character

Wants are modified through experience and changes in current patterns in a person's development from infancy to adulthood. The wants of the main character is explained by the writer in this novel.

The first wish of the main character that is told strongly in the novel is the want to leave, as seen in the following quote:

"I want to go, I lied. I've always been a bad wild, but I've been saying this lie frequently lately that it sounds almost convicting now. "Tell Charlie I said hi", "I will", "I'll see you soon," she insisted". "You come home whenever you want, I'll come right back as soon as you need me. (Page 4)

It can be seen that in this quote the narrator of the story of this novel illustrates the desire of the main character to leave but actually does not want to go to know this is contrary to his wishes

The want of the two main characters narrated in this fiction as seen in the following quote, is the wants to travel alone. That can be seen in the quote below: 
"My primary motivation behind buying a car, despite the scarcity of my funds, was that I refused to be driven around town in a car with red and blue lights on top. Nothing slows down traffic like a cop. "(page 5)

Based on the quote above, it can be analyzed that the narrator describes the main character's desire to be independent on her own, and it seems he does not want to be accompanied or followed by something that will make him look striking like his father's car headlights that can be immediately recognized and can make people slow down his vehicle in other words it explains that people will become rigid when a police car passes and he doesn't want to stand out like that.

Isabella's third wish, narrated in this fiction as seen in the following quote, is freedom to do something or not be disturbed. That can be seen in the quote below:

"One of the best things about Charlie is he doesn't hover. He left me alone to unpack and get settled, a feat that would have been altogether impossible for my mother. It was nice to be alone, not to have to smile and look pleased; a relief to staredely injected out the window at the sheeting rain and left just a few teach escape. I wasn't in the mood to go on a real crying jag. I would save that for bedtime, when I would have thought about the coming morning "(page 9).

Based on the quote above, it can be analyzed that the narrator of the story illustrates the desire of the main character who is happier because he gets a freedom without having to show a feeling of pretence. The above quote can also be explained that she wants to independently express his expression and take care of himself without any pretence. Solve the problem by finding the answer yourself.

Isabella's fourth wish, narrated in this fiction as seen in the following quote, is a must for sleep. That can be seen in the quote below:

"I didn't sleep well that night, even after I was not crying. The constant whooshing of the rain and win across the roof wouldn't fade into the background. I pulled the fade old quilt over my head, and later added the pillow, too. But I couldn't fall asleep until under midnight, when the rain finally settled into a quieter drizzle. "(Page 11)

Based on the above quote, it can be analyzed that the narrator of the story illustrates the desire of the main character to sleep at night. She found it difficult to sleep at night and his sleep to lie down so that he could forget her sadness and the burden of his mind but when he needed to be able to sleep properly for a long time until midnight.

The fifth wish of the main character narrated in the story of this novel is her want to be curious about someone, this can be seen from the following quote:

"My eyes darted back to the others, who sat unchanging. "Who are they?" I asked the girl from my Spanish class, whose name I'd forgoten ". (page 20)

Based on the above quote, the narrator in this story illustrates the desire of the main character Isabella to someone, but he asks the person who he is not yet familiar with.

The sixth wish of the main character told in this story is that he wants to go home. Her desire to do so can be seen in the following quote:

"Where do you think you're going?" He asked, outranged. He was gripping a fistful of my jacket in one hand. I was confused. "I'm going home.", "Didn't you hear me promise to take you safely home? Do you think I'm going to let you drive in your condition?" His voice was still indignant. "(Page 111)

From the quote above the main character Isabella wants to go home, but Edward realizes that her weak code is not good especially since she has fainted and still needs to be guarded.

The seventh wish of the main character told in this story is that he wants to take a picnic along. Her wants to take a picnic can be seen in the following quote: 
"So are you going? This Saturday, I mean? "I was hoping he would, even though it seemed impossible. I couldn't picture him loading up to the carpool whit the rest of the kids from school; he didn't belong in the same world. But just hoping that he might give me the first twinge of enthusiasm I felt felt the outhing. "Where are you all going, exactly?" He was still looking ahead, expressionless "" Down to La Push, to first Beach. "I studied his face, trying to read it. His eyes seemed to narrow infinitesimally, He glanced down at me from the corner of his eye, smilling wryly. "I really don't think I was visited." (Page 110) "

In connection with the above quote, it can be said that the narrator of the story illustrates the main desire to take a picnic, from here Bella invites Edward to come with him and join his friends for a picnic.

\section{Emotions of the Main Character}

Humans are usually under the influence of emotions so they can do many things that they would not do normally. The first emotional aspect of this character displayed in an imaginative story as seen in the following quote is about her worries:

"We got our jackets and headed out into the rain, which had been picked up. I could have sworn several people behind us, walking close enough to eavesdrop. I hope I wasn't getting paranoid. (Page 16)."

Regarding the above quote, it can be analyzed that the main character's emotions are her worries if he will be said to be a bother.

The second emotion of the main character narrated in this fiction is a feeling of relief/satisfaction can be seen in the following quote.

"I felt a surge of pity, and relief. Pity because, as beautiful as they were, they were outsiders, clearly not accepted. Relief that I wasn't the only newcomer here, and certainly not the most interesting by any standards." (Page 22)

In connection with the above quotation, it can be analyzed that in this quote the narrator of the novel's story explains the feelings of relief or satisfaction of the main character. She was relieved because he thought she was just a new kid who had just moved here.

The third emotion of the main character narrated in this fiction is the feeling of anger can be seen in the following quote.

"All morning I was dreading lunch, fearing his bizarre glares. Part of me wanted to confront him and demand to know what his problem was. While I was lying sleepless in my bed, I even imagined what I would say. But I knew myself too well to think I would really have the gust to do it. "(Page 30)

In connection with the above quote, it can be analyzed that in this quote the narrator of the novel's story explains about the angry feelings of the main character. below.

The next quote that shows the emotion of his feelings' main character's concern can be seen

"By Friday I was perfectly comfortable entering my Biology class, no longer worried that Edward would be there. For all I knew, he had dropped out of school. I tried not to think about him, but I couldn't totally suppress the worry. That I was responsible for his continued absence, ridiculous as it seemed. (Page 38)

From the above quote, the main character's emotions are worried about someone. She was actually not worried anymore but when she thought of Edward she was immediately worried whether she was the cause of not entering or leaving school.

Furthermore, based on research, the main character's emotions described in this novel are about her worries for vigilance as shown in the following quote.

"I walked alertly to the cafeteria with Jessica after Spanish. Mush ball were playing everywhere. I kept a blinder in my hands, ready to use it as a shield if necessary. "(Page 40) 
In connection with the above quotation, it can be learned that the author described the concern of being hit by a snowball attack from his friend.

Further found in the story is about the emotions of the main characters narrated in this fiction as seen in the following quote is the emotion of anger out of annoyance.

"Oh, I know I just wanted to ask you something while we're trapped here." This could not be happening. "Will you ask me for the spring dance?" He continued. "I'm not going to be in town, Tyler." My voice sounded a little share. I had to remember it wasn't his fault that Mike and Erik had already used up my quota of patience for the day. "(Page 81)

In connection with the quotation, it can be analyzed that the authors describe the anger of the main characters because they are upset.

D. Appetite of the main character

Human tastes are also reflected in each character of a fictional story, for example in the main character of the novel Stepenie Meyer. It can be said that the term "taste" is defined as the motive which starts and maintains the activity and also directs the activity until it finally ends with satisfaction. The first appetite of the main character connected in the story is his appetite for traveling. Can be seen from this quote.

"My primary motivation behind buying a car, despite the scarcity of my funds, was that I refused to be driven around town in a car with red and blue lights on top. Nothing slows down traffic like a cop. " (page 5)

Regarding the above quote can be analyzed that his taste for going with his own car.

The appetite of the two main characters connected in the story is his appetite for breakfast. An excerpt about hot food appetite can be seen below:

Breakfast with Charlie was a quiet event. He wished me good luck at school. I thanked him, knowing his hope wasted. (Page 11)

In connection with the quote, it can be seen that the main character's tastes are eating food for breakfast. He had breakfast before leaving for school even though breakfast only ended quietly.

The appetite of the three main characters connected in the story is his appetite for cooking for food. An excerpt about hot food appetite can be seen below:

When I got home, I unloaded all the groceries, stuffing them in where ever I could find and open space. I hope Charlie wouldn't mind. I wrapped potatoes in foil and stuck them in the oven to bake, covered a steak in marinade and balanced it on top of a carton of eggs in the fridge. (Page 33)

Based on the above quote, it can be seen that the tastes of the main characters cook for eating. Arriving at home he took out all his groceries, then stuffed them everywhere.

The appetite of the four main characters connected in the story is her appetite for dinner. An excerpt about hot food appetite can be seen below:

"What's for dinner?" He asked warily. My mother was and imaginative cook, and her experiments weren't always edible. I was surprised, and sad, that he seemed to remember that far back. "Steak and potatoes," I answered, and he looked relieve. (Page 36)

It can be seen that the main character's appetite for eating. Her father asked for dinner. The main character immediately remembers her mother who is an imaginative cook, and the experiments are always uncomfortable for peace.

The appetite of the five main characters connected in the story is her appetite for breathe in. An excerpt about breathe in appetite can be seen below:

"I breathed slowly in and out through my mouth. "Bella, are you all right?" Barnner asked. His voice was close to my head, and sounded alarmed. "I already know my blood type, Mr . Barnner, "I said in a weak voice. I was afraid to raise my hand". (Page 101) 
Based on the above quote, it can be seen that the main character's tastes for breathing slowly through his mouth. She was asked by his teacher Mr . Banner, her voice sounded very close and it surprised her.

\section{E. Feelings of the Main Character}

The term "feeling" is defined as a motive which is the opinion that is in the mind or heart of the character at the time of a special event.

The main character's awkward feelings in this story can be seen from the quote below.

"But it was sure to be awkward with Charlie. Neither of us was what anyone would call verbose, and I didn't know what was there to say regardless. I knew he was more that a little confused by my cision, like my mother before me, I hadn't made a secret of my distaste for Forks. "(Page 5)

This is awkward feeling because she knows that she is the same as her father, who doesn't like talking, meeting with Charlie, he doesn't know what to say, from where he is, he knows that Charlie is the same as him.

The second feeling experienced by the main character is the happy feeling of the main character in this story because it can be seen from the quote below.

"When I went back out to my truck, other students were stating to arrive. I dropped around the school, following the line of traffic. I was glad to see that most of the cars were older like mine, nothing flashy. At home I'd lived in one of the few lower -income neighborhoods that were included in the Paradise Valley District." (Page 14)

Referring to the above quote, it can be explained that the character's feelings are happy feelings.

Isabella's third feeling as the main character is comfort as can be seen from the following quote.

"He studied my face appretely, and I sighed. It looked like clouds and a sense of humor didn't mix. A few months of this and I'd forget how to use sarcasm. "(Page 17)

Referring to the above quote, it can be discussed that the author describes the comfortable feeling of the main character. The next feeling is the shame of the main character. It can be seen from the following quote.

"The rest of the morning passed in about the same fashion. My trigonometry teacher, Mr. Varner, who I would have hated anyway just because of the subject he taught, was the only one who made me stand in front of the class and introduce myself. I stammered, blushed, and tripped over my own boots on the way to my seat. "(Page 17)

From the above quote here the main character Isabella feels ashamed and nervous about being told to introduce herself in front of the class.

The feelings of the five main characters are awe because of the beauty of the person he sees. That can be seen from the following quote.

"I stared because their faces, so different, so similar, were all devastating, inhumanly beautiful. They were the face you never expected to see except perhaps on the airbrushed page of a fashion magazine. Or painted by an old master as the face of an angel. "(Page 19)

Regarding the above quote, it can be analyzed that the narrator of this novel illustrates the admiration of the main character.

The feeling of the six main characters is the admiration told in this fiction as seen in the following quote.

I glanced sideways at the beautiful boy, who was looking at his tray now, picking a bagelto pieces whit long, pale fingers. His mouth was moving very quickly, his perfect lips barely opening. (Page 20) 
From the above quote, it can be analyzed that the main characters describe the feeling of admiration. He was looking at someone who he thought was very handsome to look at who was pinching his bagel with those long, pale fingers.

The feelings of the seven main characters are the curiosity told in this fiction as seen in the following quote.

"Have they always like them in the forks?" I asked. Surely I would have noticed them on one of my summers here. "No," she said in a voice that implied it should be obvious, even to a new arrival like me. "(Page 22)

Based on the above quote, it can be analyzed that the main character feels curious because he wants to know about a family that he thinks is interesting to know.

The next feeling is the feeling of disappointment in the main character. This feeling of disappointment can be seen from the following quote.

They all were noticeably graceful even the big, brawny one. It was unsettling to watch. The one name Edward didn't look at me again. (Page 23)

From the quote above the narrator described the disappointment of the main character, disappointed that he saw the man who was interesting to him leave his desk, can be concluded that the main character wants them to stay there, he likes to look at those who are so perfect that even the muscular man is perfect for him very interesting attention Edward handsome man.

\section{Conclusion}

Based on the analysis of the data provided in the previous chapter, it can be concluded that aspects of the psychological life of the main character depicted in Twilight's novel by Stepenie Meyer involve many things. Matters relating to the psychological aspects described in this fiction are: (a) Human motivation, (b) wants, (c) emotions, (d) appetite, (e) feelings.

The Human motivations of the main characters explained by the narrator of this story are: (1) his want to leave, (2) his attention focused on Edward, (3) curiosity motivation, (4) Her want to make a shopping list, (5) want to invite.

The wants of the main character described by the narrator of this story are: (1) her want not to leave, (2) her want to travel alone without anyone following, (3) her want to get freedom in doing something and do not want to be disturbed, (4) a want to sleep, (5) a want to know about someone or curious, (6) a wants to go home, (7) want to invite Edward to join a picnic.

The main character's emotions are described by the narrator of this story are: (1) emotions are worries, (2) feelings of relief or satisfaction, (3) feelings of anger, (4) worries, (5) emotions are worried, (6) emotions of anger because of upset, (7) her emotions are angry.

The main character's appetite described by the narrator of this story are: (1) her appetite goes everywhere with her pickup, (2) her appetite for breakfast, (3) her appetite for cooking food and shopping, (4) her appetite for dinner, (5) breathe in.

The main character feelings depicted by the narrator in this novel are: (1) feeling awkward because it's not the type that likes to talk, (2) feeling happy, (3) feeling comfortable because she almost forgot how to be cynical, (4) feeling embarrassed, ( 5) feelings of awe, (6) feelings for awe, (7) curiosity, (8) feelings of disappointment, (9) feelings of curiosity, (10) feelings of discomfort, (11) feelings of discomfort. 


\section{Reference}

[1] R. Wellek and A. Warren, Theory of Literature. London: Cox and W Ltd, 1973.

[2] W. Kenny, How to Analyze Fiction. Manhattan: Monarch Press, 1966.

[3] K. S. Bernhardt, Practical psychology. New York: McGraw-Hill Book inc, 1953.

[4] J. Sudrajat, "A Psychological Analysis of Santiago's Motivation to Struggle Far out into the Sea as Reflected in Hemingway's the Old Man and the Sea," 2007.

[5] Y. B. Ahmad, "Psychological Approach: Emotion Analysis of the Main Character Evan Taylor in August Rush Movie by using James-Lange Theory,” UIN Syarif Hidayatullah Jakarta, 2009.

[6] S. Meyer, Twilight. New York: Little, Brown and Company, 2005. 